\title{
PERBEDAAN KONSUMSI ENERGI DAN PROTEIN BALITA STUNTING DI PEDESAAN DAN PERKOTAAN
}

\author{
Nur Afrinis ${ }^{1}$, Gusman Virgo ${ }^{2}$, Devi Kumala ${ }^{3}$ \\ Prodi Gizi, Universitas Pahlawan Tuanku Tambusai ${ }^{1,3}$ \\ Prodi Keperawatan, Universitas Pahlawan Tuanku Tambusai ${ }^{2}$ \\ afrinis.eva@gmail.com ${ }^{1}$,gusman.virgo@gmail.com²
}

\begin{abstract}
The most common nutritional problem in developing countries is stunting. Stunting in children under five year is caused by lack of food consumption in the long term. Rural areas have a higher prevalence of stunting than urban areas. The purpose of this study was to analyze differences in energi and protein consumption of stunting children under five year aged 24-59 months in rural and urban areas. This research was a quantitative study using a cross sectional design. The population in this study were children under five aged 24-59 months in Tarai Bangun Village, Tambang District and Labuh Baru Barat Village, Payung Sekaki Health Center with a total of 93 people each. The instrument used is a 24-hour food recall. The results showed that in rural areas as many as 89 children under five (95.7\%) had less energi consumption and 88 people (94.6\%) had less protein consumption. In urban areas as many as 70 toddlers (75.3) consume less energi and as many as 75 toddlers (80.6) consume less protein. The average energi consumption of stunting toddlers in rural areas were $84 \mathrm{kcal}$, while in urban areas it were $103 \mathrm{kcal}$. Based on the Mann-Whitney test, there was differences in energi intake in rural and urban areas $(p$-value $=0.000)$ and differences in protein consumption in rural and urban areas (p-value 0.004). There were significant difference between energi and protein consumption of toddlers aged 24-59 months in rural and urban areas.
\end{abstract}

Keywords

: Energi consumption, protein consumption, under five years stunting, rural, urban

\begin{abstract}
ABSTRAK
Masalah gizi yang banyak terjadi di Negara berkembang adalah stunting. Pendek (stunting) pada balita disebabkan karena kurangnya konsumsi pangan dalam jangka waktu lama. Wilayah pedesaan memiliki prevalensi stunting yang lebih tinggi daripada perkotaan. Tujuan penelitian ini untuk menganalisis perbedaan konsumsi energi dan protein balita stunting usia 24-59 bulan di pedesaan dan perkotaan. Penelitian ini merupakan penelitian kuantitatif menggunakan desain cross sectional. Populasi pada penelitian ini yaitu anak balita usia 24-59 bulan di Desa Tarai Bangun Kecamatan Tambang dan Kelurahan Labuh Baru Barat Puskesmas Payung Sekaki dengan jumlah yang masingmasing berjumlah 93 orang. Instrument yang digunakan adalah food recall 24 jam. Hasil Penelitian menunjukkan di pedesaan sebanyak 89 balita $(95.7 \%)$ konsumsi energinya kurang dan 88 orang (94.6\%) konsumsi proteinnya kurang. Di wilayah perkotaan sebanyak 70 balita $(75.3 \%)$ konsumsi energi kurang dan sebanyak 75 balita $(80.6 \%)$ konsumsi proteinnya kurang. Rata-rata konsumsi energi balita stunting di pedasaan adalah $84 \mathrm{kkal}$, sedangkan di perkotaan $103 \mathrm{kkal}$. Berdasarkan uji mann-whitney terdapat perbedaan asupan energi di pedesaan dan perkotaan $(p$-value $=0.000)$ dan perbedaan konsumsi protein di pedesaan dan perkotaan (p-value 0.004). Terdapat perbedaan yang signifikan antara konsumsi energi dan protein balita usia 24-59 bulan di pedesaan dan perkotaan.
\end{abstract}

Kata Kunci : Konsumsi Energi, Konsumsi Protein, Balita Stunting, Pedesaan, Perkotaan

\section{PENDAHULUAN}

Anak bawah lima tahun (balita) merupakan generasi penerus bangsa yang memerlukan perhatian khusus. Usia balita merupakan "usia emas" dalam pembentukan sumberdaya manusia baik dari segi pertumbuhan fisik maupun kecerdasan. Pada masa ini balita harus didukung oleh status gizi yang baik karena status gizi berperan dalam menentukan sukses tidaknya upaya peningkatan sumberdaya manusia, kekurangan atau 
kelebihan gizi bisa menyebabkan masalah gizi (Putri, Kapantow, dan Kawengian, 2015).

Masalah kesehatan yang biasa terjadi dimasa balita akan menyebabkan balita rentan mengalami penyakit yang berdampak pada status gizi dimasa selanjutnya. Status gizi merupakan suatu keadaan yang menggambarkan kesehatan pada anak yang merupakan hasil interaksi antara makanan yang dikonsumsi dan pemanfaatannya oleh tubuh (Afrinis, Verawati, dan Hendarini 2021).

Masalah gizi yang biasa terjadi adalah kurangnya konsumsi makanan dalam jangka waktu lama yang akan berdampak pada salah satunya adalah kejadian stunting (Soetjiningsih, 2008). Stunting merupakan gambaran terhambatnya pertumbuhan sebagai akibat dari kurangnya asupan zat gizi dalam jangka waktu yang lama. Menurut World Health Organization (WHO) Child Growth Standart stunting didasarkan pada indeks Panjang Badan menurut Umur $(\mathrm{PB} / \mathrm{U})$ atau Tinggi Badan menurut Umur (TB/U) dengan batas ( $\mathrm{z}$ score) kurang dari -2 SD. Stunting ditandai dengan tinggi badan menurut umur balita yang dibawah normal, balita yang sehat semakin bertambah umur semakin bertambah tinggi badannya (Departeman Kesehatan RI, 2013).

Pada tahun 2017sebanyak 22,2\% atau sekitar 150,8 juta balita di dunia mengalami stunting. Data prevalensi balita stunting yang dikumpulkan WHO Indonesia termasuk ke dalam Negara kelimadengan prevalensi tertinggi di regional Asia Tenggara/South-East Asia Regional (SEAR) setelah India, China, Nigeria, dan Pakistan. Prevalensi balita stunting di Indonesia mengalami penurunan dari tahun 2013-2018 yaitu $37,2 \%$ menjadi 30,8\% (Kemenkes, 2019). Walaupun kejadian stunting terjadi penurunan namun masih dikatakan tinggi apabila prevalensi stunting lebih dari $20 \%$ (Kemenkes, 2019).

Berdasarkan hasil Riskesdas Provinsi Riau tahun 2018 oleh Kementerian
Kesehatan RI, prevalensi status gizi balita TB/U menunjukkan bahwa anak pendek (sangat pendek dan pendek) di Riau sebesar $(27,4 \%)$ sedangkan di kota Pekanbaru sebesar (16,9\%) dan di Kabupaten Kampar sebesar $(32,1 \%)$. Tingginya angka kejadian stunting merupakan masalah yang sangat serius yang harus segera ditanggulangi karena ketika tidak ditanggulangi stunting dapat menimbulkan berbagai dampak bagi kesehatan baik itu dampak jangka pendek maupun jangka panjang.

Dampak jangka pendek dapat menyebabkan terganggunya perkembangan otak, kecerdasan, gangguan pertumbuhan fisik, dan gangguan metabolisme (semua reaksi kimia yang terjadi didalam tubuh), Sedangkan dampak jangka panjang dapat menyebabkan menurunnya kemampuan kognitif dan prestasi belajar, menurunnya kekebalan tubuh sehingga mudah sakit, dan resiko tinggi untuk munculnya penyakit diabetes, kegemukan, penyakit jantung dan pembuluh darah, kanker, stroke dan disabilitas pada usia tua (Sandjojo, 2017).

Angka kejadian stunting di Kabupaten Kampar yang paling tertinggi berada pada Puskesmas Tambang, dengan jumlah stunting sebanyak $663(23,12 \%)$ balita. Kemudian diikuti oleh puskesmas Tapung sebesar 615 (21,04\%) balita (Dinkes Kampar, 2018). Sedangkan di Kota Pekanbaru, angka kejadian stunting di Kota Pekanbaru yang paling tertinggi berada pada Puskesmas Rejosari, dengan jumlah stunting sebanyak $625(20.50 \%)$ balita. Kemudian diikuti oleh Puskesmas Payung Sekaki sebesar 610 (20.05\%) balita (Dinas Kesehatan Kota Pekanbaru, 2018). Stunting dianggap sebagai masalah yang disebabkan oleh beberapa faktor yaitu pendidikan orang tua, pekerjaan orang tua, pendapatan, konsumsi pangan pada balita dan karakteristik ibu (tinggi badan ibu) (Kemenkes, 2017).

Adapun tujuan penelitian ini adalah untuk menganalisis perbedaan konsumsi energi dan protein balita stunting usia 24-59 bulan di pedesaan dan perkotaan". 


\section{METODE}

Penelitian ini menggunakan desain cross sectional yaitu pengumpulan data baik variabel dependent maupun variabel independent dilakukan dalam waktu yang sama (Notoatmodjo, 2010). Penelitian ini dilakukan pada tanggal 02 Februari - 20 April 2019. Populasi penelitian ini adalah semua ibu yang memiliki anak balita usia 24-59 bulan yang bertempat di Desa Tarai Bangun Kecamatan Tambang yang berjumlah 135 anak balita stunting (wilayah pedesaan) dan Puskesmas Payung Sekaki, Kelurahan Labuh Baru Barat Kecamatan Payung Sekaki Kota Pekanbaru yang berjumlah 93 anak balita stunting (wilayah perkotaan). Sampel dalam penelitian ini yaitu ibu yang memiliki balita usia $24-59$ bulan di Puskesmas Tambang Desa Tarai Bangun Kabupaten Kampar (pedesaan) dan Puskesmas Payung Sekaki Kelurahan Labuh Baru Barat Kota Pekanbaru (perkotaan) yang masing-masing berjumlah 93 ibu balita. Teknik pengambilan sampling pada penelitian ini yaitu menggunakan teknik total sampling untuk di perkotaan dan simple random sampling untuk di pedesaan.

Untuk konsumsi pangan balita dikumpulkan melalui metode food recall 1 x 24 jam dikonvensikan kedalam bentuk energi dan protein dengan menggunakan Tabel Komposisi Bahan Makanan (TKPI) atau Daftar Komposisi Bahan Makanan (DKBM). Rata-rata komposisi setiap jenis pangan perhari dikonversikan kedalam energi, protein dan vitamin A tersebut dengan menggunakan rumus umum untuk mengetahui kandungan zat gizi dari bahan makanan yaitu :

$\mathrm{KGIJ}=(\mathrm{Bj} / 100) \times \mathrm{Gij} \times(\mathrm{BDDj} / 100)$

KGij : Kandungan zat gizi I bahan J

$\mathrm{Bj}$ :Berat badan makanan yang dikonsumsi (g)

Gij :Kandungan zat gizi dalam 100 gram bahan makanan $\mathrm{j}$
BDDj :Persen bahan makanan $\mathrm{j}$ yang dapat dimakan

Adapun pengelompokan konsumsi energi dan protein dikelompokkan menjadi: kurang (jika konsumsi $\leq 90$ AKG), normal (jika konsumsi 90-120\%) dan lebih (jika konsumsi $\geq 120 \%$ AKG) (Depkes, 2013).

Analisa data menggunakan analisa univariat dan bivariate. Analisi data univariat digunakan untuk menjabarkan secara deskriptif mengenai distribusi frekuensi dan proporsi masing-masing variabel yang diteliti, baik variabel bebas maupun variabel terikat (Sumantri, 2011). Analisa univariat dalam penelitian ini meliputi konsumsi energi dan protein balita stunting di pedesaan dan perkotaan. Analisa bivariate pada penelitian ini untuk menguji menentukan perbedaan variabel bebas dan variabel terikat melalui mann-whitney (Sumantri, 2011). Analisis bivariate untuk mengetahui pebedaan antara variabel independen dan dependen dan tingkat kepercayaan Confidence Interval (CI) 95\%. Jika p- value $<0.05$ berarti ada perbedaan antara konsumsi energi dan protein balita stunting di pedesaan dan perkotaan.

\section{HASIL}

Hasil penelitian diperoleh bahwa karakteristik balita berdasar jenis kelamin dari 93 balita di pedesaan sebagian besar balita yaitu sebanyak 53 responden (57\%) berjenis kelamin perempuan dan dari 93 balita diperkotaan juga sebagian besar balita sebanyak 58 responden $(62.4 \%)$ berjenis kelamin perempuan.

Metode Food Recall 24 jam yang dilihat melalui tingkatan asupan energi dan protein pada responden di pedesaan dan perkotaan.

\section{Konsumsi Energi Balita Stunting di Pedesaan dan Perkotaan}

Berdasarkan Tabel 1 dapat dilihat bahwa dari 93 balita stunting yang berada di Pedesaan sebanyak 89 balita (95.7\%) tergolong kedalam kategori konsumsi energi kurang. Sedangkan di Perkotaan 
sebanyak 70 balita $(75.3 \%)$ tergolong kedalam kategori konsumsi energi kurang.

Tabel 1. Distribusi frekuensi konsumsi energi balita stunting di Pedesaan dan Perkotaan

\begin{tabular}{lcccc}
\hline \multirow{2}{*}{ Konsumsi Energi } & \multicolumn{2}{c}{ Pedesaan } & \multicolumn{2}{c}{ Perkotaan } \\
\cline { 2 - 5 } & $\mathrm{n}$ & $\%$ & $\mathrm{n}$ & $\%$ \\
\hline Kurang & 89 & 95.7 & 70 & 75.3 \\
Normal & 4 & 4.3 & 23 & 24.7 \\
\hline \multicolumn{1}{c}{ Total } & 93 & 100 & 93 & 100 \\
\hline
\end{tabular}

Konsumsi Protein Balita Stunting di Pedesaan dan Perkotaan

Tabel 2 Distribusi frekuensi konsumsi protein balita stunting di Pedesaan dan Perkotaan

\begin{tabular}{lcccc}
\hline \multirow{2}{*}{ Konsumsi Protein } & \multicolumn{2}{c}{ Pedesaan } & \multicolumn{2}{c}{ Perkotaan } \\
\cline { 2 - 5 } & $\mathrm{n}$ & $\%$ & $\mathrm{n}$ & $\%$ \\
\hline Kurang & 88 & 94.6 & 75 & 80.6 \\
Normal & 5 & 5.4 & 18 & 19.4 \\
\hline & 93 & 100 & 93 & 100 \\
\hline
\end{tabular}

Berdasarkan Tabel 2 dapat dilihat bahwa dari 93 balita stunting di Desa Tarai Bangun sebanyak 88 balita (94.6\%) tergolong kedalam kategori konsumsi protein kurang. Sedangkan di Kota Pekanbaru sebanyak 75 balita stunting $(80.6 \%)$ berada pada konsumsi protein kategori kurang.

\section{Perbedaan Konsumsi Energi Balita} Stunting di Pedesaan dan Perkotaan

Tabel 3 Perbedaan konsumsi energi balita stunting di pedesaan dan perkotaan

\begin{tabular}{lccc}
\hline Konsumsi Energi & $\mathrm{n}$ & Mean & P-value \\
\hline Pedesaan & 93 & 84 & 0.000 \\
Perkotaan & 93 & 103 & \\
\hline
\end{tabular}

Berdasarkan Tabel 3 dapat dilihat bahwa rata-rata konsumsi energi di pedesaan $84 \mathrm{kkal}$ dan di perkotaan $103 \mathrm{kkal}$. Hasil uji analisa statistik mann-whitney menunjukkan tingkat signifikan $P$ value $=$ 0.000 dengan $P$ value $<0.05$. Hal ini membuktikan bahwa terdapat perbedaan yang signifikan antara konsumsi energi balita stunting di pedesaan dan perkotaan.

\begin{tabular}{|c|c|c|c|}
\hline \multicolumn{4}{|c|}{$\begin{array}{c}\text { Perbedaan Konsumsi Protein Balita } \\
\text { Stunting di Pedesaan dan Perkotaan } \\
\text { Tabel } 4 \text { Perbedaan Konsumsi Protein Balita } \\
\text { stunting di Pedesaan dan Perkotaan }\end{array}$} \\
\hline Konsumsi Protein & $\mathrm{N}$ & Mean & $\begin{array}{c}\mathrm{P}- \\
\text { value }\end{array}$ \\
\hline Pedesaan & 93 & 87.00 & \multirow{2}{*}{0.004} \\
\hline Perkotaan & 93 & 100.00 & \\
\hline
\end{tabular}

Berdasarkan Tabel 4 dapat dilihat bahwa hasil uji analisa statistik mannwhitney menunjukkan tingkat signifikan $P$ value $=0.004$ dengan $P$ value $<0.05$ sehingga Ho diterima. Hal ini membuktikan bahwa terdapat perbedaan yang signifikan antara konsumsi protein balita stunting di pedesaan dan perkotaan.

\section{PEMBAHASAN}

\section{Perbedaan Tingkat Konsumsi Energi Balita stunting di Pedesaan dan Perkotaan}

Konsumsi energi baik di pedesaan maupun perkotaan masih tergolong kurang. Balita membutuhkan energi besar untuk pertumbuhan dan perkembangan karena periode balita merupakan fase golden period yang mengalami growth spurt (Hardinsyah, 2016). Berdasarkan uji statistik diperoleh nilai $P$ value $=0.000$ dengan $P$ value< 0.05 sehingga Ho diterima. Hal ini membuktikan bahwa terdapat perbedaan yang signifikan antara konsumsi energi balita stunting di pedesaan dan perkotaan.

Berdasarkan hasil analisis tingkat konsumsi energi balita stunting di pedesaan dan perkotaan menunjukkan bahwa terdapat perbedaan tingkat konsumsi energi antara balita stunting yang tinggal di wilayah pedesaan dan balita stunting yang tinggal di wilayah perkotaan. Pada kedua wilayah konsumsi energi balita sebagian besar masuk dalam kategori defisit. Rata-rata konsumsi energy diperkotaan lebih tinggi dibandingkan pedesaan. 
Hasil penelitian ini tidak sejalan dengan penelitian yang ditemukan oleh Lestari, Wanda dkk dimana rendahnya kecukupan energi merupakan faktor risiko pada kejadian stunting. Pada penelitian tersebut anak stunting lebih banyak anak dengan tingkat kecukupan energi yang kurang $(\mathrm{p}=0,03)$. Demikian juga penelitian Aridiyah tahun 2015 menyatakan hubungan tingkat kecukupan energi dengan kejadian stunting pada anak balita menunjukkan hasil bahwa tingkat kecukupan energi antara anak balita yang berada di daerah pedesaan maupun perkotaan tidak memiliki hubungan terhadap terjadinya stunting pada anak balita.

Menurut Helmi (2013) konsumsi energi kurang dari kebutuhan dalam jangka waktu lama akan menghambat pertumbuhan, bahkan mengurangi cadangan energi dalam tubuh hingga terjadi keadaan gizi kurang maupun buruk. Hal ini berdampak pada gangguan pertumbuhan fisik, mempunyai badan yang pendek, mengalami gangguan perkembangan mental dan kecerdasan terhambat.

Menurut asumsi peneliti kurangnya asupan energi balita banyak terdapat di pedesaan dari pada perkotaan disebabkan tingkat pendidikan ibu dan kurangnya informasi yang didapat oleh ibu. Hal ini sesuai dengan teori Almatsier dkk (2011) menyatakan asupan energi kurang yang terjadi pada anak usia 24-60 bulan karena factor-faktor yang mempengaruhi dari orang tua yaitu kebiasaan menerima makanan dan pengetahuan gizi dari orang tua tersebut. Asupan energi kurang lebih banyak terjadi pada usia 24-60 bulan, hal itu disebabkan oleh perilaku makan anak tersebut yang susah/rewel makan.

\section{Perbedaan Tingkat Konsumsi Protein Balita Stunting di Pedesaan dan Perkotaan}

Tingkat konsumsi protein balita stunting di pedesaan dan perkotaan berada pada kategori kurang. Berdasarkan uji statistik chi-square diperoleh $\mathrm{P}$ value = $0.004<0.05$. Hal ini membuktikan bahwa terdapat perbedaan yang signifikan antara konsumsi protein balita stunting di pedesaan dan perkotaan.

Sumber protein di perkotaan yang dikonsumsi lebih variatif bila dibandingkan dengan di pedesaan. Sumber dari hewani lebih dominan dikonsumsi, antara lain daging ayam, telur dan ikan serta berbagai olahannya. Sumber protein di wilayah pedesaan yang sering dikonsumsi antara lain telur, ayam, tempe, tahu dan kacangkacangan. Sumber-sumber dari nabati yang paling sering dikonsumsi di wilayah ini, sedangkan untuk sumber dari hewani sangat jarang mereka konsumsi. Hal ini disebabkan

karena harga dari sumber hewani lebih mahal bila dibandingkan dengan sumber nabati. Hal ini mungkin berkaitan dengan pekerjaan orangtua mereka yang sebagian besar bermata pencarian sebagai petani, karyawan pabrik dan buruh lepas, sehingga akan berdampak pula dengan penghasilan.

Selain itu rendahnya konsumsi protein pada balita disebabkan kurangnya informasi yang didapat ibu dari media maupun petugas kesehatan, kesibukan urusan rumah tangga lainnya. Kurangnya perhatian ibu terhadap porsi makan balita, kebanyakan ibu menuruti selera balita seperti saat recall hari biasa balita makan lebih sedikit dibandingkan di hari libur. Begitu juga terhadap lauk pauk, kebanyakan ibu menuruti selera balita sehingga apabila balitanya suka makan telur maka ibu sering memberikan telur oleh karena itu kebutuhan protein yang didapat tidak beragam.

\section{KESIMPULAN}

Konsumsi energi dan protein balita stunting di pedesaan dan perkotaan berada pada kategori kurang. Rata-rata konsumsi energi dan protein balita di perkotaan lebih tinggi dibanding pedesaan. Terdapat perbedaan yang signifikan antara konsumsi energi, dan protein balita stunting usia 2459 bulan di pedesaan dan perkotaan. 


\section{UCAPAN TERIMAKASIH}

Ucapan terima kasih terutama ditujukan kepada LPPM dan pihak Universitas Pahlawan Tuanku Tambusai yang telah memberikan dana untuk penelitian ini. Ucapan terima kasih juga kepada pihak Puskesmas Tambang Kabupaten Kampar dan Puskesmas Payung Sekaki Kota Pekanbaru dan responden yang membantu pelaksanaan penelitian.

\section{DAFTAR PUSTAKA}

Afrinis, Nur, Besti Verawati, and Any Tri Hendarini. 2021. "Analisis Faktor Yang Berhubungan Dengan Status Gizi Bayi Usia 6-12 Bulan Pada Masa Pandemi Covid-19.” PREPOTIF : Jurnal Kesehatan Masyarakat 5(1):304-10.

Almatsier, S., Soetardjo, S., \& Soekarti, M. 9 (2011). Gizi seimbang dalam daur kehidupan. Jakarta : PT Gramedia Pustaka Utama.

Aridiyah, et al. 2015. Faktor-faktor yang Mempengaruhi Kejadian Stunting pada Anak Balita di Wilayah Pedesaan dan Perkotaan. E-jurnal Pustaka Kesehatan, 3(1): 163-170.

Depkes RI. 2013. Profil Kesehatan Indonesia. Jakarta: Kemenkes RI.

Dinas Kesehatan Kabupaten Kampar. 2018. Prevalensi Status Gizi Di Kabupaten Kampar.

Dinas Kesehatan Kota Pekanbaru. 2018. Prevalensi Status Gizi di Kota Pekanbaru.

Direktorat Jenderal Bina Gizi dan Kesehatan Ibu dan Anak. Keputusan Menteri Kesehatan. Jakarta: Kementerian Kesehatan RI; 2011.

Hardinsyah, Supariasa DW. 2016. Ilmu Gizi Teori dan Aplikasi. Jakarta (ID): EGC

Helmi, Rosmalia. 2013. Faktor-faktor yang Berhubungan dengan Status Gizi pada Balita di Wilayah Kerja Puskesmas Margototo Kecamatan
Metro Kibang Kabupaten Lampung Timur. Jurnal Kesehatan, Volume IV, Nomor 1. April 2013. hlm 233-242

Kemenkes RI.(2017). Data dan Informasi Profil Kesehatan Indonesia 2016.

Pusat Data dan Informasi. Jakarta.

Kemenkes RI. 2019. Kebijakan dan Strategi Penanggulangan Stunting di Indonesia. Jakarta.

Lestari, Wanda dkk. 2014. Faktor risiko stunting pada anak umur 6-24 bulan di kecamatan Penanggalan kota Subulussalam provinsi Aceh. Jurnal Gizi Indonesia (ISSN : 1858-4942) Vol. 3, No. 1, Desember 2014: 37-45

Lamid A. 2015. Masalah Kependekan (Stunting) pada Anak Balita.: Analisis Prospek Penanggulangannya di Indonesia. Bogor: PT Penerbit IPB Press.

Notoatmodjo S. 2010. Metodologi Penelitian Kesehatan. Jakarta : Rineka Cipta.

Pusat Data dan Informasi. 2018. Situasi Balita Pendek (Stunting) di Indonesia. Jakarta: Kemenkes RI.

Putri, Maya S., Nova Kapantow, and Shirley Kawengian. 2015. "Hubungan Antara Riwayat Penyakit Infeksi Dengan Status Gizi Pada Anak Batita Di Desa Mopusi Kecamatan Lolayan Kabupaten Bolaang Mongondow." Jurnal EBiomedik 3(2):1-

Sandjojo E. 2017. Buku Saku Desa dalam

Penanganan Stunting. Jakarta:

Kementrian Desa, Pembangunan

Daerah Tertinggal, dan Transmigrasi.

Soetjiningsih. (2008). Tumbuh Kembang Anak. Jakarta:EGC.

Sumantri A. 2011. Metode Penelitian Kesehatan. Jakarta (ID) : Kencana. 